\title{
Koetjapic acid, a natural triterpenoid, induces apoptosis in colon cancer cells
}

\author{
ZEYAD D. NASSAR $^{1}$, ABDALRAHIM F.A. AISHA ${ }^{1}$, NORSHIRIN IDRIS ${ }^{1}$, \\ MOHAMED B. KHADEER AHAMED ${ }^{1}$, ZHARI ISMAIL ${ }^{2}$, KHALID M. ABU-SALAH ${ }^{3}$, \\ SALMAN A. ALROKAYAN ${ }^{3}$ and AMIN MALIK SHAH ABDUL MAJID ${ }^{1}$
}

Departments of ${ }^{1}$ Pharmacology, and ${ }^{2}$ Pharmaceutical Chemistry, School of Pharmaceutical Sciences, Universiti Sains
Malaysia, Minden 11800, Pulau Penang, Malaysia; ${ }^{3}$ The Chair of Cancer Targeting and Treatment, Biochemistry
Department and King Abdullah Institute for Nanotechnology, King Saud University, 2454, Riyadh 11451, Saudi Arabia

Received May 27, 2011; Accepted June 28, 2011

DOI: 10.3892/or.2011.1569

\begin{abstract}
Deregulated cell signaling pathways result in cancer development. More than one signal transduction pathway is involved in colorectal cancer pathogenesis and progression. Koetjapic acid (KA) is a naturally occurring seco-A-ring oleanene triterpene isolated from the Sandoricum koetjape stem bark. We report the cellular and molecular mechanisms of anticancer activity of KA towards human colorectal cancer. The results showed that KA induces apoptosis in HCT 116 colorectal carcinoma cells by inducing the activation of extrinsic and intrinsic caspases. We confirmed that KA-induced apoptosis was mediated by DNA fragmentation, nuclear condensation and disruption in the mitochondrial membrane potential. Further studies on the effect of KA on cancer pathways show that the compound causes down-regulation of Wnt, HIF-1 $\alpha$, MAP/ERK/JNK and Myc/Max signaling pathways and up-regulates the NF- $\mathrm{KB}$ signaling pathway. The result of this study highlights the anticancer potential of KA against colorectal cancer.
\end{abstract}

\section{Introduction}

Colon cancer is the third most common malignancy worldwide (1). Chemotherapeutic agents target neoplastic tissues by activating the apoptotic machineries in cancer cells. The frequency of apoptosis could contribute to cell loss in tumors and promote tumor regression (2). Apoptosis is accompanied by a series of morphological changes including cell shrinkage, plasma and nuclear membrane blebbing, organelle re-localization and compaction, chromatin condensation and production

Correspondence to: Dr Amin Malik Shah Abdul Majid, Department of Pharmacology, School of Pharmaceutical Sciences, Universiti Sains Malaysia, Minden 11800, Pulau Penang, Malaysia E-mail: aminmalikshah@gmail.com

Key words: Koetjapic acid, Sandoricum koetjape, colorectal cancer, apoptosis, Wnt pathway of membrane-enclosed particles containing intracellular material known as apoptotic bodies (3).

Natural products are considered as a mainstay in cancer treatment, $60 \%$ of worldwide anticancer drugs between 1983 and 1994 are from natural origin (4). The impact of natural products in cancer treatment is clearly obvious, paclitaxel and camptothecin were estimated to account for nearly one-third of the global anticancer market or about $\$ 3$ billion of $\$ 9$ billion in total annually in 2002 (5). Triterpenes are class of phytochemicals which have been found to have strong anticancer activity towards a variety of cancers including colorectal cancer (6). S. koetjape is a terpenoids-rich traditional medicinal plant belonging to the family Meliaceae, native to Malaysia, Cambodia and Southern Laos (7). Our previous studies reported strong antiangiogenic and cytotoxic effects of n-hexane extract of $S$. koetjape on human colon cancer cell line (HCT 116), however, the underlying mechanism was not known (8). Koetjapic acid (KA) is a seco-A-ring oleanene triterpene isolated from $S$. koetjape and was found to have mild cytotoxicity on a number of human cancer cell lines and murine lymphocytic leukemia $(7,9)$. KA has been found to have anti-bacterial, anti-inflammatory, anti-tumor promoting activity and DNA polymerase inhibition properties (10-13). In this study, an attempt has been made to understand the cellular and molecular mechanisms involved in cytotoxic effects of KA towards colon cancer. We also investigated the effect of KA on the activity of the transcription factors of the major 10 pathways involved in carcinogenesis of colon cancer and other cancers as well. The reporter systems consist of transcription factor responsive constructs namely TCF/LEF, RBP-Jk, p53, SMAD2/SMAD3/SMAD4, E2F/DP1, NF-кB, Myc/Max, HIF-1, Elk-1/SRF, and AP-1 which monitor the transcription factor activity of Wnt, Notch, p53, TGF $\beta$, cell cycle, NF- $\kappa B$, Myc/Max, HIF-1, MAPK/ERK and MAPK/JNK pathways, respectively.

\section{Materials and methods}

Chemicals and reagents. RPMI-1640 cell culture medium, modified Eagle's medium (MEM), Dulbecco's modified 
Eagle's medium (DMEM), trypsin and heat inactivated foetal bovine serum (HIFBS) were obtained from Gibco, UK. Phosphate-buffered saline (PBS), penicillin/streptomycin (PS) solution, MTT reagent, rhodamine 123 and Hoechst 33258 were purchased from Sigma-Aldrich, USA.

Cell lines and culture conditions. Human colorectal carcinoma (HCT 116, ATTC $^{\circledR}$ CCL-1658 ${ }^{\mathrm{TM}}$ ), human hormone resistant breast cancer cell line (MDA-MB-231, ATTC $^{\circledR}$ HTB- $26^{\mathrm{TM}}$ ), human hepatocarcinoma cell line (Hep G2, ATTC $^{\circledR}$ HB- $8065^{\mathrm{TM}}$ ) and human normal colon cell line (CCD-18Co, ATTC ${ }^{\circledR}$ CRL-1459 ${ }^{\mathrm{TM}}$ ) were purchased from ATCC (Rockville, MD, USA). HCT 116 cells were maintained in RPMI-1640 containing 10\% HIFBS and 1\% PS. Hep G2 were cultured in MEM supplemented with 10\% HIFBS and $1 \%$ PS. MDA-MB-231 and CCD-18Co cells were propagated in DMEM containing 10\% HIFBS and 1\% PS. Cells were cultured in a $5 \% \mathrm{CO}_{2}$ in a humidified atmosphere at $37^{\circ} \mathrm{C}$.

Isolation and characterization of KA. KA was isolated from S. koetjape stem bark as previously described (9). Briefly, $10 \mathrm{~g}$ of n-hexane extract was crystallized at $-20^{\circ} \mathrm{C}$ in $50 \mathrm{ml}$ methanol:acetone at $1: 1 \mathrm{v} / \mathrm{v}$. The collected crystals $(500 \mathrm{mg})$ were re-crystallized in chloroform by solvent evaporation to give colourless prism-shaped crystals $(400 \mathrm{mg})$. The melting point of the compound was recorded using DSC. The IR Spectrum was recorded with $\mathrm{KBr}$ pellets on a Thermo nexus FT-IR spectrophotometer. The ${ }^{1} \mathrm{H}$ NMR spectrum was recorded in (DMSO-d6) at $298 \mathrm{~K}$ on a Bruker $400 \mathrm{MHz}$ Ultrashied $^{\mathrm{TM}}$ FT-NMR spectrometer equipped with a $5 \mathrm{~mm}$ BBI inverse gradient probe. The shift of chemicals was referenced to internal tetramethylsilane (TMS). Standard Bruker pulse programs were used throughout the experiment. Mass spectra were obtained using a LC-MSD-Trap-VL Electrospray ion (ESI) mass spectrometer (Agilent Technologies) by direct infusion method. The samples were prepared in HPLC grade methanol and were injected directly into the ESI source at a flow rate of $5 \mu \mathrm{l} / \mathrm{min}$. The MS conditions were as follows: negative ion mode; gas (N2) temperature, $325^{\circ} \mathrm{C}$; flow rate, $5.0 \mathrm{l} / \mathrm{min}$; nebulizer pressure, $15 \mathrm{psi}$; $\mathrm{HV}$ voltage, $4.0 \mathrm{kV}$; octopole RF amplitude, $150 \mathrm{Vpp}$; skim 1 voltage, $-38.8 \mathrm{~V}$; skim 2 voltage, $-6.0 \mathrm{~V}$; capillary exit, $-113.8 \mathrm{~V}$; cap exit offset, $-75.0 \mathrm{~V}$ and scan range, m/z 350-550 units. Acquired mass spectra represented average of five spectra.

Cell proliferation assay. Cytotoxicity of the KA was evaluated by MTT assay against a panel of human cancer cell lines, viz. HCT 116 (colon), MDA-MB-231 (breast) and Hep G2 (liver). Human colonic fibroblast (CCD-18Co) was used as a normal cell model. Cells were treated for $48 \mathrm{~h}$ with KA or $1 \%$ ethanol as a negative control. Viability of cells were determined by MTT assay (14). Assay plates were read using microtiter plate reader (Hitachi U-2000, Japan) at $A_{570}$. The results are presented as percent viability to the negative control (mean $\pm S D, n=3$ ).

Colony formation assay. Effect of KA on clonogenicity of HCT 116 cells was studied (15). In brief, 1000 cells/well in single cell suspension were plated in 6-well plates. Attached cells were treated with KA, betulinic acid (positive control) or $1 \%$ ethanol (negative control). After 48 -h treatment, media containing the test compounds was removed, cells were washed twice with PBS and fresh media was added. After 7 days the cells were fixed with $4 \%$ paraformaldehyde and stained with $0.2 \%$ crystal violet. The colonies of $>50$ cells were counted and the plating efficiency (PE) and the survival fraction (SF) were calculated. Result is expressed as mean $\pm \mathrm{SD}(\mathrm{n}=3)$.

Effect of KA on caspases-3/7, -8 and -9 activities. Following 3-h treatment with KA caspase-3/7, -8, -9 activities were measured in HCT 116 cells, using Glo 3/7, Glo 8 and Glo 9 assay systems (Promega, USA). In brief, caspase reagent was added to the treated cells at $1: 1 \mathrm{v} / \mathrm{v}$ to the medium. The plate was then incubated for $30 \mathrm{~min}$ at room temperature and the luminescence was measured in a plate-reading luminometer (HIDEX, Finland). Result are expressed as mean \pm SD $(n=3)$.

Determination of nuclear condensation by Hoechst 33258 stain. Overnight incubated HCT 116 cells were treated with two concentrations of KA and analysed separately at two different time intervals (6 and $18 \mathrm{~h}$ ). The cells were fixed in 4\% paraformaldehyde for 20 min before staining with Hoechst $33258 \mathrm{stain}(1 \mu \mathrm{g} / \mathrm{ml}$ in PBS) for $30 \mathrm{~min}$. Nuclear condensation and cytoplasmic shrinkage were examined under a fluorescent microscope (Olympus, Japan). Cells with bright condensed or fragmented nuclei were considered apoptotic. The number of cells with apoptotic morphology was counted in four randomly selected fields per well. The apoptotic index was calculated as percentage of apoptotic nuclei compared to the total number of cells and presented as a mean $\pm S D(n=3)$.

DNA fragmentation assay. HCT 116 cells $\left(5 \times 10^{6}\right)$ were treated with various concentrations of KA for $24 \mathrm{~h}$. DNA was extracted with Wizard ${ }^{\circledR}$ SV Genomic DNA Purification kit (Promega). DNA was analyzed by electrophoresis for $2 \mathrm{~h}$ at $100 \mathrm{~V}$ in $1.2 \%$ agarose gel stained with ethidium bromide. DNA fragments were visualized under ultraviolet light. This experiment was repeated twice.

Effect on mitochondrial potential. To study the effect on mitochondrial membrane potential, HCT 116 cells were treated with KA and were assessed for retention of rhodamine 123. Confluent culture of HCT 116 was treated with $\mathrm{KA}$ at $20 \mu \mathrm{g} / \mathrm{ml}$ for 6- and 18 -h intervals then fixed with $4 \%$ paraformaldehyde for $20 \mathrm{~min}$ and stained with rhodamine $123(5 \mu \mathrm{g} / \mathrm{ml})$ for $30 \mathrm{~min}$. The cells were photographed using an inverted fluorescent microscope at x20 magnification. Cells with depolarized mitochondria appear more brightly stained than normal non-apoptotic cells $(16,17)$. Brightly stained cells were counted in four randomly selected fields per well. The apoptotic index was calculated as percentage of apoptotic mitochondria compared to the total number of cells and presented as a mean $\pm \operatorname{SD}(n=3)$.

Luciferase assay. The effect of KA on the 10 different transcription factors involved in carcinogenesis was investigated by the Cignal ${ }^{\mathrm{TM}}$ Reporter Assay (SA Biosciences, USA). The assay was performed in 96-well plate format according to the manufacturer's instructions. Briefly, HCT 116 cells were transfected by reverse transfection method using Trans Fast ${ }^{\circledR}$ liposome transfection reagent (Promega, USA). After over- 
A

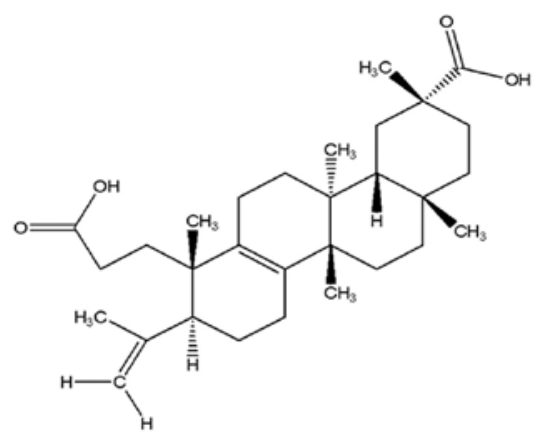

B

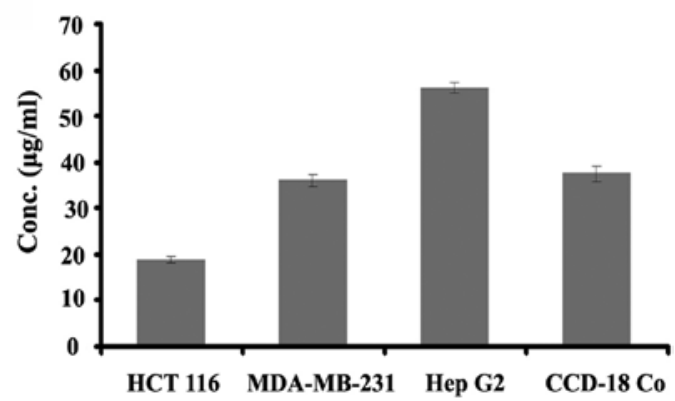

Figure 1. (A) Chemical structure of the koetjapic acid. (B) Effect of KA on proliferation of three human tumor cell lines (HCT 116, MDA-MB-231 and Hep G2) and normal CCD-18Co cell line. The calculated $\mathrm{IC}_{50}$ values were $19 \pm 0.7,36 \pm 1.2,56 \pm 1.2$ and $37.47 \pm 1.39$, respectively. The cells were exposed to $\mathrm{KA}$ for $48 \mathrm{~h}$. Values represent the means of three experiments $\pm \mathrm{SD}$.

night incubation, the old medium was aspirated and replaced with $75 \mu \mathrm{l}$ RPMI complete medium containing KA at $25 \mu \mathrm{g} /$ $\mathrm{ml}$ or the vehicle. After 6-h treatment, luciferase activity was measured by Dual Luciferase Reporter System (Promega). The luminescence was measured by microplate reader (HIDEX, Finland) and the Firefly/Renilla ratio was generated for each treatment. The result of each particular pathway is presented as a mean of the fold change (relatively to untreated cells) \pm SD $(n=3)$.

Statistical analysis. Results are presented as the means $\pm \mathrm{SD}$ and differences between groups were compared by the one-way ANOVA and considered significant at $\mathrm{P}<0.05,0.01$ or 0.001 . The statistical analysis was carried out by using SSPS edition 16.0 .

\section{Results}

Chemical characterization of $K A$. The $\mathrm{KBr}$ infrared spectrum unambiguously revealed the presence of hydroxyl, carbonyl and olefinic groups in the molecule. The broad peak corresponds to the stretching frequency of - $\mathrm{OH}$ group. A typical singlet is observable at $1659 \mathrm{~cm}^{-1}$ which is assigned to the $\mathrm{C}=\mathrm{O}$ stretching mode $\left(1659 \mathrm{~cm}^{-1}\right)$. A prominent peak at the region $1548 \mathrm{~cm}^{-1}$ corresponds to olefinic group in the structure. The ${ }^{1} \mathrm{H}$ NMR spectrum of the compound contained resonances corresponding to eight methyl groups in the region range between $\delta 0.8760$ and 1.7154 all as singlets. The methylene protons $\left(22 \mathrm{H}\right.$ of $\left.11 \mathrm{CH}_{2}\right)$ resonated as a multiplet at $\delta 2.4857$ to 2.5103 and two 2 protons for two olefinic groups were observed at $\delta 4.6655$ and 4.8819 . Thus, the compound was considered to

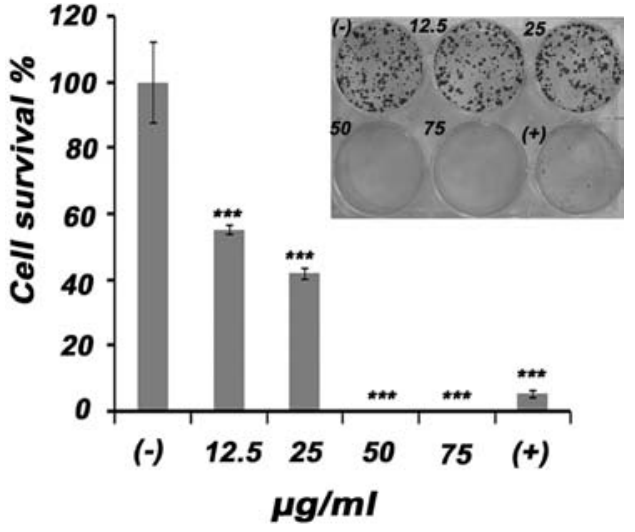

Figure 2. Clonogenic cell survival of HCT 116 cells treated with: (-), $1 \%$ ethanol as a negative control; (+), $20 \mu \mathrm{g} / \mathrm{ml}$ of betulinic acid as a positive control and indicated concentration of KA. Data pooled from two experiments with error bars representing the standard deviation of means. The plating efficiency was $38.1 \pm 4.6 \%$.

be a secotriterpene. Based on the evidential data from IR and ${ }^{1} \mathrm{H}$ NMR spectra of the compound suggested the presence of C-3,4-seco-olean-4,12-diene carbon skeleton in the structure and it was characterized as (3,4-seco-olean-4(23),20-diene3,30-dioic acid which is commonly known as koetjapic acid (Fig. 1A). The compound was found to exhibit a molecular ion at $470.3 \mathrm{~m} / \mathrm{z}$ on high-resolution mass spectrometry, indicating an elemental composition of $\mathrm{C}_{30} \mathrm{H}_{46} \mathrm{O}_{4}$. The measured mp was $290-292^{\circ} \mathrm{C}$, the reported $\mathrm{mp}$ was $296-298^{\circ} \mathrm{C}$ (7). The crystallographic structure of KA was resolved by X-ray crystallography as previously described (9).

Anti-proliferative efficacy of $K A$. Cytotoxicity of KA was evaluated using MTT assay on HUVECs, HCT 116, MDA-MB-231 and Hep G2 cell lines. KA was found more cytotoxic on the colorectal cancer HCT 116 cells with median inhibitory concentration $\left(\mathrm{IC}_{50}\right) \quad 18.88 \pm 0.65 \mu \mathrm{g} / \mathrm{ml}$ when compared to other cell lines $(\mathrm{P}=0.000)$ (Fig. 1B). The clonogenicity study on HCT 116 cells indicated KA to be cytotoxic rather than cytostatic as evident by the decrease in the SF. The PE was $38.1 \pm 4.6 \%, \mathrm{SF}$ at 50 and $75 \mu \mathrm{g} / \mathrm{ml}$ was almost $0.0 \%$. However, at lower concentrations, 12.5 and $25 \mu \mathrm{g} / \mathrm{ml}$, the SF was $55.3 \pm 1.6 \%$ and $41.9 \pm 1.4$, respectively (Fig. 2).

KA induces apoptosis by activating caspase-3/7, -8 and -9 . An attempt was made to study the mechanism of cell death caused by KA. Treatment of HCT 116 cells for $3 \mathrm{~h}$ was found sufficient to cause significant induction of caspases-3/7 activities. Further studies on the initiator caspases -8 and -9 showed a 3-fold increment of the caspase activity in HCT 116 cells treated with KA when compared to untreated cells. Statistical analysis indicates that the induction of caspase- 9 activity was moderately higher than caspase- 8 , which indicates stronger role of the mitochondrial pathway in cell death induced by KA (Fig. 3).

KA induced morphological changes and nuclear condensation of HCT 116 cells. Effect of KA on nuclear morphology of HCT 116 cells was investigated by staining the nucleus with 
A

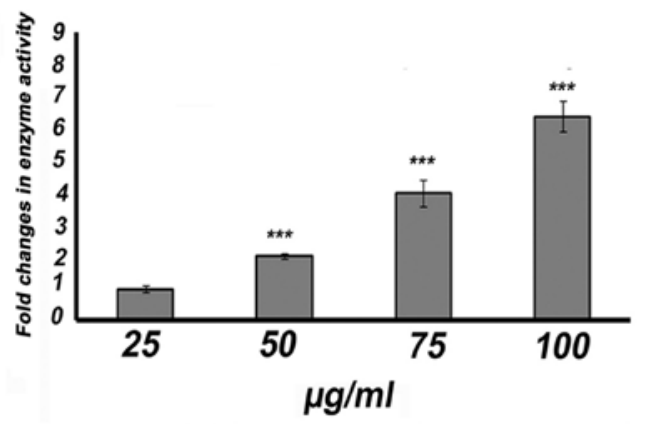

B

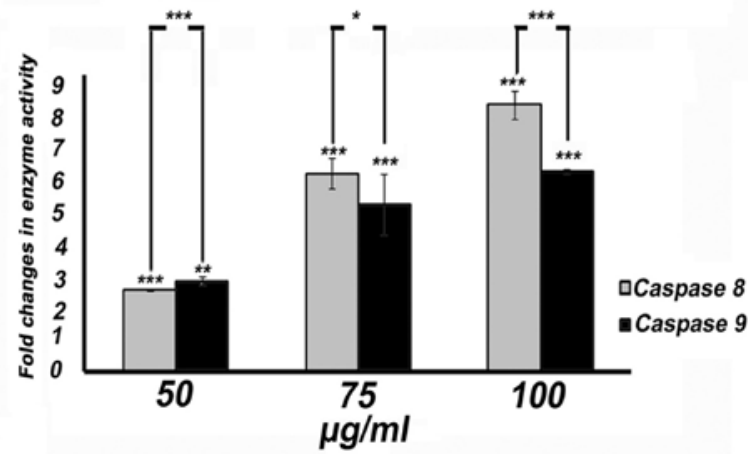

Figure 3. (A) Effect of KA on caspase-3/7, -8 and -9 activities. Fold induction was calculated by dividing the values obtained from KA-treated samples by the readings obtained from control treated samples (1\% ethanol). (B) Induction of upstream caspase- 8 and -9 activities by KA. Induction of caspase-9 activity is more significant than caspase-8. Cells treated for $3 \mathrm{~h}$ with $1 \%$ ethanol as a negative control or the indicated concentrations of KA.

Hoechst 33258 stain. Only the cells treated with vehicle showed uniform staining of nucleus. On the contrary, typical changes in the chromatin structure were observed in cells treated with $\mathrm{KA}$ at $40 \mu \mathrm{g} / \mathrm{ml}$. The chromatin structure condensed progressively in a dose- and time-dependent manner forming clusters against the nuclear periphery and/or crescent shaped cell morphology at higher concentrations (Fig. 4A). At $20 \mu \mathrm{g} / \mathrm{ml}$, KA caused the nuclei to shrink and the chromatin to collapse into high density structures. The apoptotic indices after 6- and 18-h treatment with $\mathrm{KA}$ at $40 \mu \mathrm{g} / \mathrm{ml}$ were $27.3 \pm 6.88$ and $60.3 \pm 3.89 \%$, respectively, and at $20 \mu \mathrm{g} / \mathrm{ml}$, the apoptotic indices were $12 \pm 1.4$ and $30 \pm 5.21 \%$, respectively.

$K A$ caused DNA fragmentation. To investigate the effect of KA on late events of apoptosis, DNA of treated HCT 116 cells was analyzed on agarose gel electrophoresis. A clear dose-dependent laddering pattern was observed within the concentration range of 10-40 $\mu \mathrm{g} / \mathrm{ml}$ (Fig. 4B).

$K A$ reduces mitochondrial membrane potential. Rhodamine 123 , a cationic fluorescent dye whose mitochondrial fluorescence intensity decreases quantitatively in response to dissipation of mitochondrial transmembrane potential, was used to evaluate disturbances in mitochondrial membrane potential (16). Cells were exposed to rhodamine 123 and the intensity of rhodamine in the cells was observed. Rhodamine was readily taken up by the untreated cells, whereas minimum uptake of rhodamine is seen in the treated cells (Fig. 4C). The apoptotic indices after 6- and 18-h treatment with KA at with $20 \mu \mathrm{g} / \mathrm{ml}$ were $20.4 \pm 6.3$ and $30.1 \pm 2.7 \%$, respectively. This result signifies that, there is a reduction in the mitochondrial membrane potential of HCT 116 cell line after treating with KA.
A

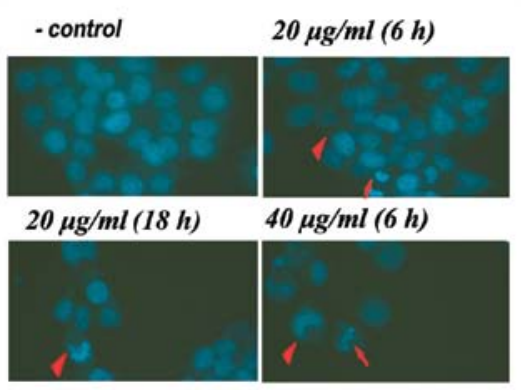

$40 \mu \mathrm{g} / \mathrm{ml}(18 \mathrm{~h})$
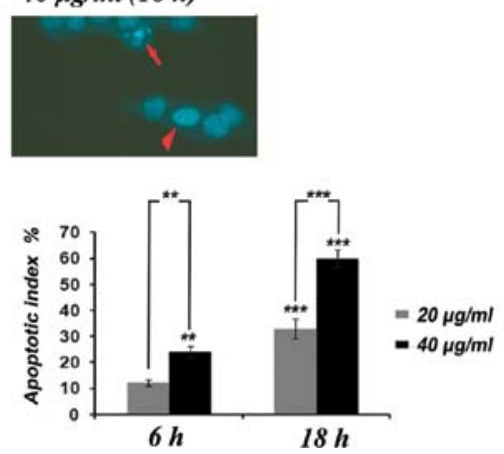

B

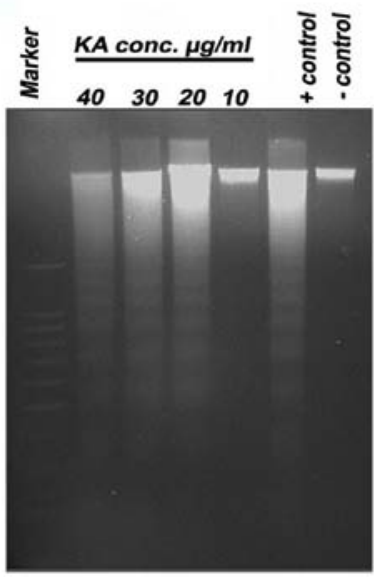

C
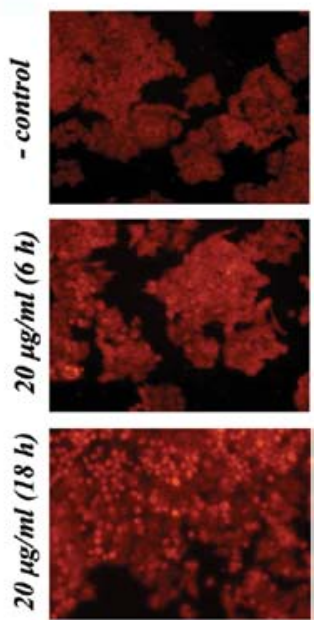

Figure 4. (A) Effect of KA on morphology of nuclei of HCT 116 cells. Images show Hoechst 33258-stained nucleus after 6- and 18-h treatment with 1\% ethanol or indicated concentrations of KA. The treated cells demonstrate typical apoptotic morphology: condensation of the nuclear material (arrows) and formation of apoptotic bodies (arrows heads) (x40 magnification). (B) Effect of KA on DNA fragmentation. HCT 116 cells were treated with $1 \%$ ethanol (negative control), betulinic acid at $20 \mu \mathrm{g} / \mathrm{ml}$ (positive control) and the indicated concentrations of KA for $24 \mathrm{~h}$. (C) KA effect on mitochondrial membrane potential and rhodamine 123 uptaking after exposing the HCT 116 cells to $1 \%$ ethanol or KA at $20 \mu \mathrm{g} / \mathrm{ml}$ for 6 and $18 \mathrm{~h}(\mathrm{x} 20 \mathrm{magnification}) .{ }^{*} \mathrm{P}<0.05,{ }^{* *} \mathrm{P}<0.01$ and ${ }^{* * * *} \mathrm{P}<0.001$. 


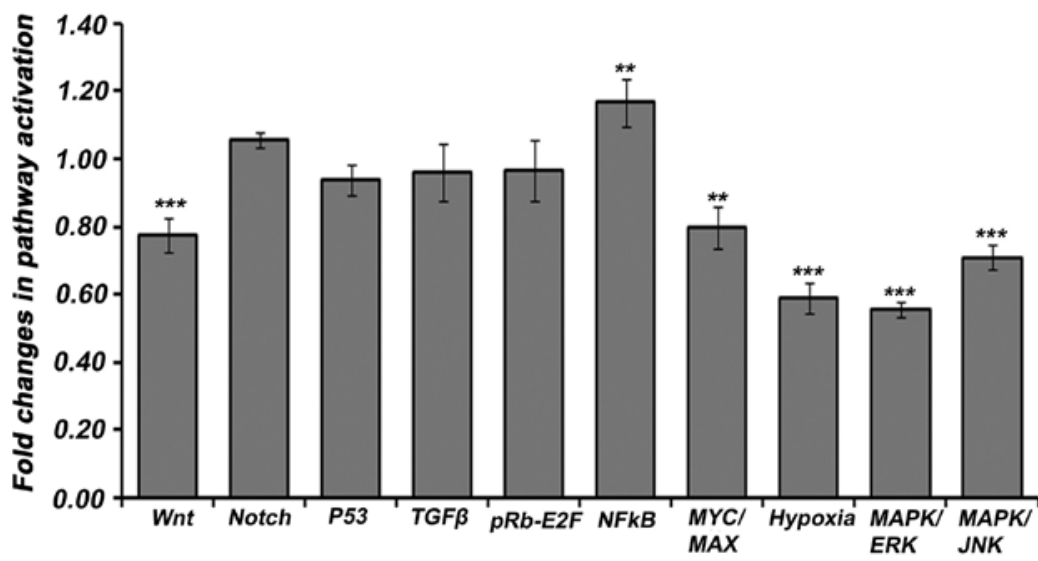

Figure 5. Effects of KA on apoptotic signaling pathways in HCT 116 cell line. Significant decrease in cancer reporter gene activities was noted for proproliferative pathways including Wnt, c-Myc, hypoxia, MAPK/ERC and MAPK /JNK, and significant up-regulation of NF- $\mathrm{BB}$ pathway can be seen in KA $(25 \mu \mathrm{g} / \mathrm{ml})$. No significant changes were detected in Notch, P53, TGF $\beta$ and pRb-E2F. The luminescence reading for each reporter was determined by using a dual-luciferase reporter system for both, the treated cells and untreated cells. The fold change in transcriptional factor activities were calculated by determining the ratio between (Firefly/Renilla) luminescence reading of treated cells and (Firefly/Renilla) luminescence reading of untreated cells for each pathway. Error bars indicate standard deviations from mean. ${ }^{*} \mathrm{P}<0.05,{ }^{* *} \mathrm{P}<0.01$ and ${ }^{* * *} \mathrm{P}<0.001$.

KA modulates the transcription level of carcinogenesis pathways in HCT 116. The study on 10 carcinogenesis pathways revealed that KA has an extensive influence on multiple pathways as indicated by the modulation in the transcriptional activity relative to untreated cells. KA caused significant up-regulation of NF- $\kappa B(1.17 \pm 0.07$-fold). On the other hand, the compound caused significant down-regulation in the transcriptional activity of five major pathways namely MAPK/JNK $(0.71 \pm 0.04)$, MAPK/ERK $(0.56 \pm 0.02)$, HIF- $1 \alpha(0.59 \pm 0.04)$, MYC/MAX $(0.8 \pm 0.06)$ and Wnt $(0.78 \pm 0.06)$. However, no significant changes were observed in transcriptional activity of Notch, p53, TGF $\beta$ and pRb-E2F (Fig. 5).

\section{Discussion}

Previously, we have shown that n-hexane extract of S. koetjape bark has potent cytotoxic activity as well as anti-angiogenic properties (8). Fractionation and crystallization of the extract has led to a more detailed understanding of the KA molecular structure confirming previous findings $(7,9)$. In this study, our results show that KA has significant anticancer activity towards HCT 116 colorectal carcinoma cells via the apoptotic pathways. KA compound was found to be selectively more cytotoxic towards HCT $116\left(\mathrm{IC}_{50} 18.88 \mu \mathrm{g} / \mathrm{ml}\right)$ than MDA-MB231, CCD-18Co and Hep G2 (Fig. 1B).

HCT 116 cells treated with KA displayed elevated levels of caspase-8 and -9 as well as caspase-3/7 (Fig. 3). These findings are complimentary with work done by other researchers who have shown that caspase- 8 alone may be insufficient to execute cell death, thus, it concomitantly interacts with the intrinsic apoptotic pathway by causing damage to mitochondrial membrane which in turn releases cytochrome c (18). We found that KA caused a dose dependent DNA fragmentation, nuclear fragmentation and chromatin condensation in HCT 116 cells leading to apoptotic body formation (Fig. 4A and B). We also studied the effect of KA on cell colony formation in order to assess if the cytotoxic effect of KA on HCT 116 cells is reversible. The colony formation assay is also able to distinguish between cytotoxic and cytostatic compounds (19). The calculated $\mathrm{IC}_{50}$ of $\mathrm{KA}$ in this assay was $15.78 \mu \mathrm{g} / \mathrm{ml}$. The effect was found to be cytotoxic rather than cytostatic as evidenced by a decrease in a clonogenic survival (Fig. 2). The results showed that KA perturb the ability of single cells to grow into colonies, thus KA inhibited the proliferative properties of HCT 116 cells.

Failure in reducing the MTT reagent into formazan salt, elevated levels of caspase-9 and -3 in HCT 116 cells and significant decrease in rhodamine fluorescent intensity after treatment with KA suggest that KA may have caused mitochondrial damage (Fig. 4C). The result of the rhodamine study implies that, KA can induce mitochondrial permeability transition through an increase in intracellular cation concentrations, and can cause a significant loss in mitochondrial membrane potential which is an important prerequisite in the activation of apoptosis (20).

To detect the possible signaling pathways that contribute to apoptotic cell death in HCT 116 cells caused by KA, we assessed the early changes in a series of signaling pathways controlling cell cycle and apoptosis. The effect of KA on ten signaling pathways involved in colorectal cancer pathogenesis and progression was investigated by measuring the activity of the transcriptional factors representing these pathways namely TCF/LEF (Wnt), RBP-JK (Notch), p53 (p53/DNA damage), SMAD 2/3/4 (TGF 3 ), E2F/DP1 (cell cycle/pRb-E2F), NF-kB (NF-kB), Myc/Max (Myx/Max), HIF-1 $\alpha$ (Hypoxia), Elk-1/ SRF (MAPK/ERK), AP-1 (MAPK/JNK). Wnt signaling is important in maintaining stemness in normal colon stem cells and hyper-activation of this pathway is common in most colon cancers (21). Around $80 \%$ of sporadic colon cancer patients have mutation in the tumor suppressor gene APC and its function was identified as a down-regulator of Wnt pathway (22). It is widely accepted now that mutations either in APC or Wnt/ $\beta$-catenin pathway are the earliest events in colon oncogenesis (23). Using Wnt signaling activity as a readout, we found that KA caused down-regulation of Wnt possibly by affecting the formation of $\beta$-catenin/Tcf4 complexes (24). Many studies 
have highlighted the important role of Wnt- $\beta$-catenin pathway in colorectal cancer and their potential as the optimal target for cancer drugs $(25,26)$.

Based on numerous basic and clinical observations, $\mathrm{NF}-\kappa \mathrm{B}$ suppression is often interpreted as a potential future of chemotherapeutics to curb tumorigenesis (27). Nevertheless, recently this proposal has been challenged by several tumor models, particularly in colorectal cancer (28), in which $\mathrm{NF}-\kappa \mathrm{B}$ activation has been hypothesized as a safeguard against tumorigenesis. In addition to regulating cellular responses to cytokines and pathogens, the $\mathrm{NF}-\kappa \mathrm{B}$ pathway plays an essential role in controlling cellular growth properties and apoptotic cell death (29). In the present study, our findings showed a significant up-regulation of NF- $\mathrm{NB}$ pathway in KA treated HCT 116 cells. This result correlates with that of aspirin on colon cancer cells (28). Aspirin, a non-steroidal anti-inflammatory drug, induces apoptosis in colon cancer cells by up-regulating the NF- $\kappa \mathrm{B}$ signaling pathway. KA was reported to have anti-inflammatory property (13), and most probably similar to aspirin, it may stimulate $\mathrm{NF}-\kappa \mathrm{B}$ through nuclear translocation of NF- $\kappa \mathrm{B}$ complexes.

Another important element in cancer is the Myc cellular protein. Myc has a vital role in the proliferation of cells, and is crucial for the maintenance of stem cell compartments and the balance between self-renewal and differentiation in multiple tissues, including the intestinal crypts (30). Myc is deregulated and overexpressed in most cancer cells, where it impairs the diverse intracellular and extracellular regulators of proliferation of normal cells and transforming them into cancer cells (31). Therefore, inhibition of Myc gene may evolve into a useful chemotherapeutic strategy. In the present study, the results show that KA significantly suppressed Myc pathway expression. This provides an additional complementary and substantial evidence of the compound's anticancer efficiency.

In addition to the pathways discussed above, c-Jun $\mathrm{NH}(2)$-terminal protein kinases (JNK) and extracellular signal-regulated kinase (ERK) pathways were also investigated, which are the active members of mitogen-activated protein kinase (MAPK) family. MAP kinases are serinethreonine protein kinases involved in cellular responses to mitogen stimulation, environmental stress, proinflammatory cytokines, and apoptotic stimuli. This pathway is essential for G1- to S-phase progression. MAPKs also serve in stabilization of c-MYC protein (32). Additionally, MAPKs down-regulate more than 170 tumor suppressor genes such as: Tob1, JunD and Ddit3 which inhibit cell growth and proliferation (33).

Recent studies have shown that MAPK cascade plays a central role in angiogenesis by specifically inducing VEGF mRNA expression (34). MAPK cascade controls growth and survival directly at the level of tumor cells and by its paracrine action via VEGF secretion, hence it represents a target of choice for therapeutic intervention in cancer. In this study, we found KA caused a significant down-regulation of these MAPK associated genes that could provide supporting evidence for pro-apoptotic activity.

The findings have revealed that few transcriptional factors (TGF $\beta$, Notch, pRb-E2F and p53) are not affected upon treatment with KA. It is not clear whether p53-independent apoptosis is a common phenomenon induced by large number of drugs or p53-independent apoptosis pathways are rare
(35). Many drugs were reported to induce independent p53 apoptosis for instance, taxol (36). p53 is mutated in about 50\% of human tumors (37), which may contribute to resistance to major chemotherapeutics. Thus, identifying drugs that induce p53-independent apoptosis is valuable.

The result of this study clearly highlights the potential use of KA in prevention or treatment of colon cancer by targeting the multiple genes that are critical in carcinogenesis.

\section{Acknowledgements}

Z.D.N. and A.F.A.A. would like to acknowledge USM for the USM Fellowship. This study was financially supported by Universiti Sains Malaysia (USM) Research University Grant (Grant 1001/PFARMASI/811144), and supported partially by the research chair funded by King Saud University on Drug Targeting and Treatment of Cancer Using Nanoparticles.

\section{References}

1. Parkin DM, Bray F, Ferlay J and Pisani P: Global cancer statistics, 2002. CA Cancer J Clin 55: 74-108, 2005.

2. Naik P, Karrim J and Hanahan D: The rise and fall of apoptosis during multistage tumorigenesis: down-modulation contributes to tumor progression from angiogenic progenitors. Genes Dev 10: 2105-2116, 1996

3. Bold RJ, Termuhlen PM and McConkey DJ: Apoptosis, cancer and cancer therapy. Surg Oncol 6: 133-142, 1997.

4. Cragg GM, Newman DJ and Snader KM: Natural products in drug discovery and development. J Nat Prod 60: 52-60, 1997.

5. Oberlies NH and Kroll DJ: Camptothecin and taxol: historic achievements in natural products research. J Nat Prod 67: 129-135, 2004.

6. Mahato SB and Sen S: Advances in triterpenoid research, 19901994. Phytochemistry 44: 1185-1236, 1997.

7. Kaneda N, Pezzuto J, Kinghorn A, et al: Plant anticancer agents, L. cytotoxic triterpenes from Sandoricum koetjape stems. J Nat Prod 55: 654-659, 1992.

8. Aisha AFA, Sahib H, Abu-Salah K, Darwis Y and Abdul Majid A: Cytotoxic and anti-angiogenic properties of the stem bark extract of Sandoricum koetjape. Int J Cancer Res 5: 105-114, 2009.

9. Nassar ZD, Aisha AFA, Majid AMSA, Yeap CS and Fun HK: Koetjapic acid chloro-form hemisolvate. Acta Crystallogr Sect E Struct Rep Online 66: O1301-O1302, 2010.

10. Ismail IS, Ito H, Mukainaka T, et al: Ichthyotoxic and anticarcinogenic effects of triterpenoids from Sandoricum koetjape bark. Biol Pharm Bull 26: 1351-1353, 2003.

11. Sun DA, Starck SR, Locke EP and Hecht SM: DNA polymerase beta inhibitors from Sandoricum koetjape. J Nat Prod 62: 1110-1113, 1999.

12. Muhammad I, El Sayed KA, Mossa JS, et al: Bioactive 12-oleanene triterpene and secotriterpene acids from Maytenus undata. J Nat Prod 63: 605-610, 2000.

13. Rasadah MA, Khozirah S, Aznie AA and Nik MM: Antiinflammatory agents from Sandoricum koetjape Merr. Phytomedicine 11: 261-263, 2004.

14. Mosmann T: Rapid colorimetric assay for cellular growth and survival: application to proliferation and cytotoxicity assays. J Immunol Methods 65: 55-63, 1983.

15. Franken N, Rodermond HM, Stap J, Haveman J and van Bree C: Clonogenic assay of cells in vitro. Nat Protocol 1: 2315-2319, 2006.

16. Rahn CA, Bombick DW and Doolittle DJ: Assessment of mitochondrial membrane potential as an indicator of cytotoxicity. Fundam Appl Toxicol 16: 435-448, 1991.

17. Ghosh $\mathrm{J}$ and Myers CE: Inhibition of arachidonate 5-lipoxygenase triggers massive apoptosis in human prostate cancer cells. Proc Natl Acad Sci USA 95: 13182-13187, 1998.

18. Ghobrial IM, Witzig TE and Adjei AA: Targeting apoptosis pathways in cancer therapy. CA Cancer J Clin 55: 178-194, 2005. 
19. Plumb JA: Cell sensitivity assays: clonogenic assay. In: Cancer Cell Culture: Methods and Protocols. Langdon SP (ed). Humana Press Inc., Totowa, NJ, pp159-165, 2004.

20. Polla BS, Kantengwa S, Francois D, et al: Mitochondria are selective targets for the protective effects of heat shock against oxidative injury. Proc Natl Acad Sci USA 93: 6458-6463, 1996.

21. Sancho E, Batlle E and Clevers H: Signaling pathways in intestinal development and cancer. Annu Rev Cell Dev Biol 20 695-723, 2004.

22. Calvert PM and Frucht H: The Genetics of colorectal cancer. Ann Intern Med 137: 603-612, 2002.

23. Kinzler KW and Vogelstein B: Lessons from hereditary colorectal cancer. Cell 87: 159-170, 1996.

24. Clevers H: Wnt breakers in colon cancer. Cancer Cell 5: 5-6, 2004.

25. Pendas-Franco N, Aguilera O, Pereira F, Gonzalez-Sancho JM and Munoz A: Vitamin D and Wnt/beta-catenin pathway in colon cancer: role and regulation of DICKKOPF genes. Anticancer Res 28: 2613-2623, 2008.

26. Luu HH, Zhang R, Haydon RC, et al: Wnt/beta-catenin signaling pathway as a novel cancer drug target. Curr Cancer Drug Targets 4: 653-671, 2004.

27. Mayo MW and Baldwin AS: The transcription factor NF-kappaB: control of oncogenesis and cancer therapy resistance. Biochim Biophys Acta 1470: M55-M62, 2000.

28. Stark LA, Din FVN, Zwacka RM and Dunlop MG: Aspirininduced activation of the NF- $\kappa$ B signaling pathway: a novel mechanism for aspirin-mediated apoptosis in colon cancer cells. FASEB J: 1273-1275, 2001.
29. Barkett M and Gilmore T: Control of apoptosis by Rel/NF-kappaB transcription factors. Oncogene 18: 6910-6924, 1999.

30. Murphy MJ, Wilson A and Trumpp A: More than just proliferation: Myc function in stem cells. Trends Cell Biol 15: 128-137, 2005.

31. Soucek L, Whitfield J, Martins CP, et al: Modelling Myc inhibition as a cancer therapy. Nature 455: 679-683, 2008.

32. Sears R, Nuckolls F, Haura E, Taya Y, Tamai K and Nevins JR Multiple Ras-dependent phosphorylation pathways regulate Myc protein stability. Genes Dev 14: 2501-2514, 2000.

33. Yamamoto T, Ebisuya M, Ashida F, Okamoto K, Yonehara S and Nishida E: Continuous ERK activation downregulates antiproliferative genes throughout G1 phase to allow cell-cycle progression. Curr Biol 16: 1171-1182, 2006.

34. Pages G, Milanini J, Richard DE, et al: Signaling angiogenesis via p42/p44 MAP kinase cascade. Ann N Y Acad Sci 902: $187-200,2000$

35. Erdal H, Berndtsson M, Castro J, Brunk U, Shoshan MC and Linder S: Induction of lysosomal membrane permeabilization by compounds that activate p53-independent apoptosis. Proc Natl Acad Sci USA 102: 192-197, 2005.

36. Wahl AF, Donaldson KL, Fairchild C, et al: Loss of normal p53 function confers sensitization to Taxol by increasing G2/M arrest and apoptosis. Nat Med 2: 72-79, 1996.

37. Béroud $\mathrm{C}$ and Soussi T: p53 gene mutation: software and database. Nucleic Acids Res 26: 200-204, 1998. 